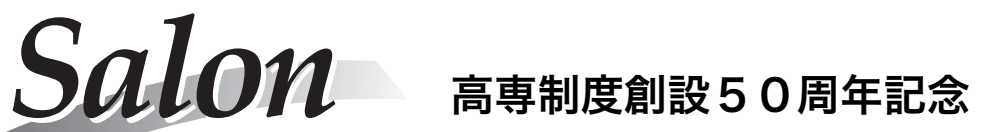 \\ 高専制度発足 50 周年を迎えて 一独立行政法人化後の取組み一
}

\section{高橋 英明（旭川工業高等専門学校 校長）}

\section{1. はじめに}

昭和 37 年, 全国各地に 12 の工業高等専門学校が設立さ れてから，半世紀が経過した。現在，国立 51 校，公立 3 校, 私立 3 校, 計 57 校の高専が存在する。 “高専” と言えば, 多くの方は“ロボコン”を思い出すかもしれない，筆者の 勤務する旭川高専は, 全国優勝 2 回, ロボコン大賞受賞 1 回を誇る強豪校であるが，このような高専の歴史・特徵 なぞに関する記述は多いと思うので，本稿においては， 独立行政法人化後の国立高専の取り組みについて述べる.

\section{2. 第 1 期中期目標 - 中期計画期間（平成 16 年 平成 20 年)}

独立行政法人化とともに，(独) 国立高専機構は，5年間 の中期目標・中期計画の立案が義務づけられた。第 1 期 においては，1) スケールメリットを生かした統括的・効 率的運営の構築および2) 教育の高度化を目指した高専の 統廃合が行われた。各高専の物品購入・出張旅費支払い などの事務は，機構本部で一括管理されるようになった。 第二期に入っても事務の効率化は続行され，危機・リス ク管理，ICネットワークの構築などが現在進行中である。

高専の統合・再編は, 同一県内に複数校ある地域で議 論され, 平成 21 年, 宮城工業高専と仙台電波高専が統合 して仙台高専になったのを筆頭に, 富山高専, 香川高専 および熊本高専が新しく生まれ，55 校あった国立高専が， 51 校となった。これらの統合・再編にあたっては，本科 の学科数を削減する一方, 専攻科の定員が本科学生数の $10 \%$ から, 最大 $25 \%$ 一拡大され，いわゆる専攻科の重点 化が図られている。また，これらのいわゆる“スーパー高 専” は，地域連携，国際交流などの地区基幹校としての役 割を持つ。他の地域での高専の統廃合も議論されている が，現在のところ新しい高専の設立には至っていない.

\section{3. 第二期中期目標 -中期計画（平成 21 年～平成 25 年)}

第二期においては，1) 国際的に活躍できる人材の育成, 2) 地域連携・社会貢献に基づいた教育の高度化，3）モデ ルコアカリキュラムの作成等が, 新しい改革のポイント として挙げられる。

グローバル人材の育成は, 我が国, 喫緊の課題である が，高専においては，「海外工場を任せられる技術者の育 成」が, 話題に上る. 平成 22 年, 留学生交流促進セン ターが設置され, 私費留学生の獲得に努めている. 今年 度には 11 名の私費留学生が各地の高専に入学した。海外 工場インターンシップは, 学生が, 我が国の企業の海外 工場で約 1ヶ月働く制度で, 全国の高専より 20-30人の学
生が選抜される. ISATE (International Symposium on Advances of Technology Education) は, 全国の高専教員と 包括提携をしている海外の大学の教員が集まって技術者 教育に関して議論する国際会議である。また ISTS (International Symposium on Technology for Sustainability) は, 全国の高専専攻科の学生が, 海外の学生と一緒に研究発 表と議論を行う場である。このような試みは, 海外に行 くチャンスの少ない, 高専の教員・学生の国際的意識を 高める格好の機会となっている.

高専の地域連携は, 各校の地域共同テクノセンターを 中心に進められており, 技術相談 - 共同研究 - 受託研究 の他, Co-op 教育, インターンシップなどを扱っている. また, 科研費を始めとする外部資金の獲得は, 大学に比 べて低いものの，年々増大している.

高専教育における人材養成像は, 設立当時の “中堅技術 者”から “発想豊かな実践的技術者（1998大学審議会答 申)”, “応用力にとんだ実践的・創造的技術者（2005 中教 審答申)”, “より高度で幅広い場で活躍する実践的・創造 的技術者 (2008 中教審答申)”へと変化しており,この新 しい技術者の養成のためのカリキュラムが, 本年 3 月に モデルコアカリキュラム (試案) として発表された。 各 高専における教育の実態を調査・分析し, 専攻科をも含 む各分野の到達目標とミニマムスタンダードを定めたも のである. 現在, 各高専で内容の検証を行っており, 平 成 26-27年度にその定着を目指している。

\section{4. 終わりに}

15 歳人口の減少, 若者の理科離孔, 高学歴社会への移 行, ものづくり産業の海外移転など, 高専を取り巻く環境 は, 大きく変化しょうとしている. 本稿では触れなかった が, 入学試験制度, 編入学制度, 学位授与制度, 長岡・ 豊橋両技科大との連携なぞ, それらの動向が, 最近大きく 変化しつつあり, 高専の抱える課題は少なくない.

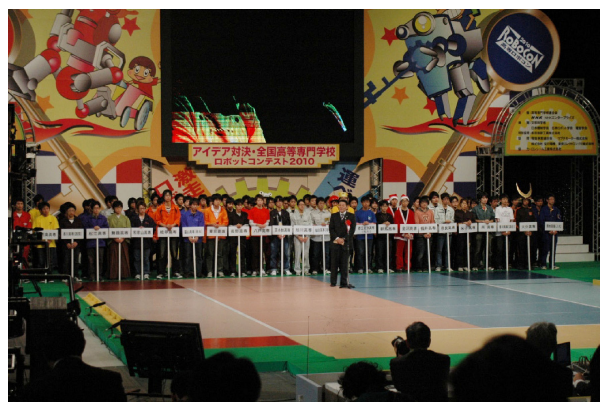

Figure 1. (Color online) 平成 22 年度アイデア対決・全国高 専ロボコン開会式風景. 